\title{
THE EFFECTS OF CHLORPROMAZINE TREATMENT ON THE SECRETORY ACTIVITY OF CORPORA LUTEA IN HYSTERECTOMIZED SHEEP
}

\author{
S. P. COUDERT AND R. V. SHORT \\ Department of Veterinary Clinical Studies \\ and A.R.C. Unit of Reproductive Physiology and Biochemistry, Cambridge
}

(Received 3rd February 1968)

\begin{abstract}
Summary. The treatment of hysterectomized sheep with massive doses of chlorpromazine for 6 days did not depress the secretory activity of their corpora lutea. Since chlorpromazine is likely to inhibit pituitary LH secretion and enhance prolactin secretion, these results suggest that prolactin may be luteotrophic in the ewe.
\end{abstract}

The secretion of follicle stimulating hormone (FSH) and luteinizing hormone (LH) by the anterior pituitary is thought to be under the control of specific hypothalamic releasing factors (FSH-RF and LH-RF), whereas pituitary prolactin secretion is normally restrained by a hypothalamic inhibitory factor (P-IF) (Harris \& Donovan, 1966). Experimentally, one can interfere with the secretion of these hypothalamic factors by severing the pituitary stalk, and hence interrupting the hypothalamo-hypophysial portal system, or by using centrally active depressant drugs with an action on the hypothalamus, such as chlorpromazine. If hypothalamic activity is impaired in this way, it follows that FSH and LH secretion will be decreased and prolactin secretion increased.

It has recently been shown that pituitary stalk section in the ewe does not immediately interfere with the secretion of progesterone by the corpus luteum, suggesting that prolactin may have a luteotrophic action in the sheep (Denamur, Martinet \& Short, 1966). However, one cannot be certain that stalk section abolishes all pituitary FSH and LH secretion; releasing factors may still reach the pituitary through the systemic circulation, and in addition there may be a considerable amount of anterior lobe tissue in the pars distalis, proximal to the cut stalk. The purpose of the present experiment was to see if pharmacological, as opposed to surgical, interference with the hypothalamo-hypophysial system had any effect on pituitary luteotrophin secretion in the ewe.

Eight ewes were hysterectomized between the 7th and 13th day of the oestrous cycle and the corpora lutea were marked with Indian ink. Twenty-one days later, $100 \mathrm{ml}$ of blood was withdrawn from the jugular vein into a heparinized syringe. The plasma was separated by centrifugation and frozen. Six of the ewes were then placed on twice daily chlorpromazine injections for 5 or 6 days, and two were kept as untreated controls. Three of the treated animals received $6 \mathrm{mg} / \mathrm{kg}$ twice daily for 6 days (Nos. 576, 577 and 587); at higher dosage rates it was sometimes necessary to modify the dose depending on the clinical state of 
the animal. The dosages given to three such animals (Nos. 571, 583 and 589) are summarized in Text-fig. 1.

At the end of the treatment period, a further sample of $100 \mathrm{ml}$ peripheral blood was collected and the plasma frozen. All the animals were then anaesthetized with sodium pentobarbitone and blood was collected from one of the veins draining the ovary with the marked corpus luteum, and the plasma frozen. The animals were then killed under the anaesthetic and the marked corpora lutea enucleated from the ovaries and frozen.
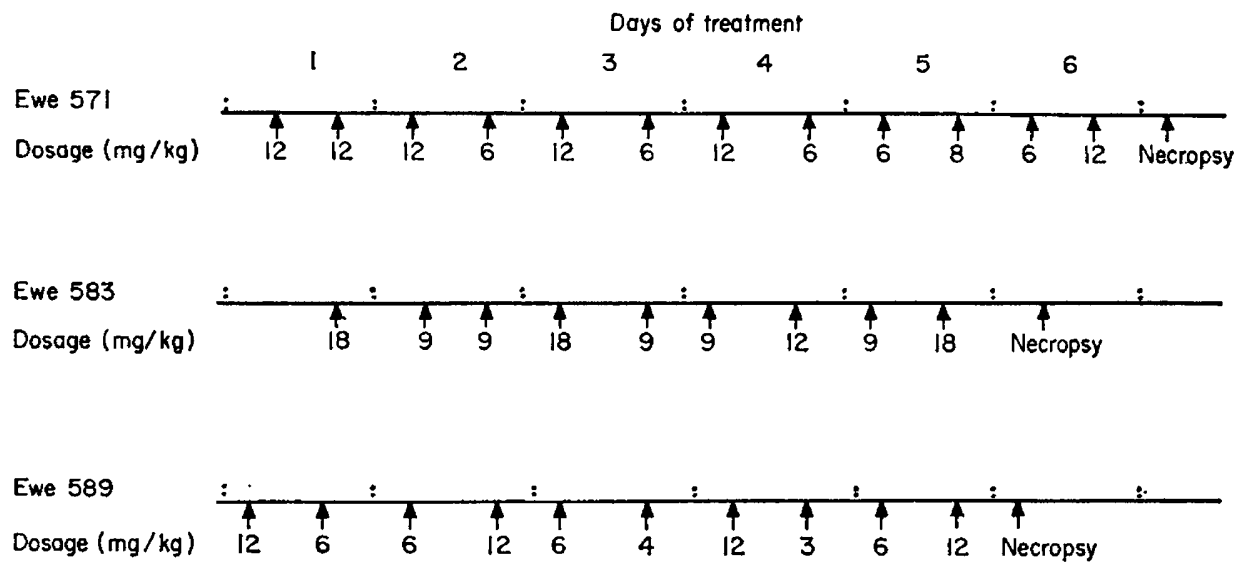

TEXT-FIG. 1. Details of chlorpromazine treatment of ewes 571, 583 and 589.

Progesterone was measured in all the plasma samples by the gas chromatographic technique of Schomberg, Coudert \& Short (1967). For luteal tissue, the technique of Rowlands \& Short (1959) was used, final quantitation being achieved by gas chromatography. All results were corrected for extraction losses by the use of an internal isotope standard of $7\left[{ }^{3} \mathrm{H}\right]$ progesterone.

The results are summarized in Table 1. Although there were considerable variations between animals in the peripheral progesterone concentrations, the values are within the range of those found during the luteal phase of the normal cycle and during pregnancy (Short \& Moore, 1959). There were no consistent changes in the peripheral levels in response to chlorpromazine treatment.

The concentrations of progesterone in ovarian vein plasma were also within the normal range (Short, 1964), except for the right ovary of animal No. 589, where the value was low. The corpus luteum from this ovary also had a low progesterone concentration, whereas all the other luteal concentrations were within the normal range (Collins, Inskeep, Howland, Pope \& Casida, 1966; Deane, Hay, Moor, Rowson \& Short, 1966) or even slightly elevated.

If hysterectomized ewes are subsequently hypophysectomized, there is a marked fall in the progesterone concentration in ovarian vein blood and luteal tissue within $48 \mathrm{hr}$ of the operation (Denamur et al., 1966 and unpublished observations). However, if the animals are stalk sectioned, the corpus luteum continues to secrete large amounts of progesterone for up to 2 weeks (Denamur et al., 1966). The effects of chlorpromazine treatment observed in this study 
are, therefore, similar to those of stalk section, and unlike those of hypophysectomy.

Robertson \& Rakha (1965) showed that a single injection of chlorpromazine at a dosage rate of $12 \mathrm{mg} / \mathrm{kg}$ given to ewes at the onset of oestrus will block ovulation for at least $36 \mathrm{hr}$. Thus it seems likely that the dosages we have used (12 to $22 \mathrm{mg} / \mathrm{kg} /$ day) would have been sufficient to cause considerable

\section{TABLE 1}

PROGESTERONE CONCENTRATIONS IN PERIPHERAL PLASMA, OVARIAN VEIN PLASMA AND LUTEAL TISSUE OF HYSTERECTOMIZED EWES BEFORE AND AFTER GHLORPROMAZINE TREATMENT

\begin{tabular}{|c|c|c|c|c|c|}
\hline \multirow{3}{*}{ Animal No. } & \multirow{3}{*}{$\begin{array}{c}\text { Chlorpromazine } \\
\text { treatment } \\
\text { (mg/kg/twice daily) }\end{array}$} & \multicolumn{3}{|c|}{$\begin{array}{l}\text { Progesterone concentrations } \\
(\mu \mathrm{g} / 100 \mathrm{ml} \text { plasma })\end{array}$} & \multirow{3}{*}{$\begin{array}{c}\text { Progesterone in } \\
\text { luteal tissue } \\
(\mu g / g)\end{array}$} \\
\hline & & \multicolumn{2}{|c|}{ Peripheral } & \multirow[b]{2}{*}{ Ovarian vein } & \\
\hline & & $\begin{array}{c}\text { Before } \\
\text { treatment }\end{array}$ & $\begin{array}{c}\text { After } \\
\text { treatment }\end{array}$ & & \\
\hline 570 & 0 & 0.46 & 0.66 & $256 \cdot 0$ & $44 \cdot 5$ \\
\hline 579 & 0 & 0.31 & 0.26 & $177 \cdot 0$ & $64 \cdot 2$ \\
\hline 576 & 6 & 0.51 & 0.30 & $220 \cdot 0$ & $43 \cdot 3$ \\
\hline 577 & 6 & 1.09 & 0.69 & $\begin{array}{l}\text { R } 349 \cdot 0 \\
\text { L } 463 \cdot 0\end{array}$ & $\begin{array}{ll}\text { R } & 55 \cdot 3 \\
\text { L } & 51 \cdot 5\end{array}$ \\
\hline 587 & 6 & 0.40 & 0.41 & $202 \cdot 0$ & $49 \cdot 3$ \\
\hline 571 & Approx. $10^{*}$ & 0.70 & 0.59 & $69 \cdot 6$ & $86 \cdot 7$ \\
\hline 589 & Approx. 8* & $0 \cdot 18$ & 0.19 & $\begin{array}{l}\mathrm{R} \quad 11 \cdot 4 \\
\mathrm{~L} \cdot 225 \cdot 0\end{array}$ & $\begin{array}{lr}R & 5 \cdot 3 \\
L & 66 \cdot 9\end{array}$ \\
\hline 583 & Approx. 11* & 0.38 & 0.54 & $\begin{array}{l}\text { R } 282 \cdot 0 \\
\text { L } 373 \cdot 0\end{array}$ & 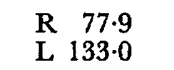 \\
\hline
\end{tabular}

* See Text-fig. 1 for exact dosages.

inhibition of pituitary FSH and LH secretion. The animals on the higher dosages certainly became deeply depressed. The fact that the corpus luteum can continue to secrete normally when the hypothalamus is pharmacologically inhibited in this way lends further support to the contention that prolactin is likely to be luteotrophic in the ewe.

One of us (S.P.C.) acknowledges an Anglo-French Clinical Research Grant awarded jointly by the Medical Research Council and the Institut National de la Santé et de la Recherche Médicale. We would also like to thank $\mathrm{Mr}$ L. E. A. Rowson and Dr R. M. Moor for carrying out the hysterectomies for us.

\section{REFERENCES}

Collins, W. E., Inskeep, E. K., Howland, B. E., Pope, A. L. \& Casida, L. E. (1966) Effects of hysterectomy and corpus luteum induction on pituitary-ovarian relationships in the ewe. 7. Anim. Sci. 25, 87.

Deane, H. W., Hay, M. F., Moor, R. M., Rowson, L. E. A. \& Short, R. V. (1966) The corpus luteum of the sheep: relationships between morphology and function during the oestrous cycle. Acta endocr., Copenh. 51, 245. 
Denamur, R., Martinet, J. \& Short, R. V. (1966) Secretion de la progesterone par les corps jaunes de la brebis après hypophysectomie, section de la tige pituitaire et hystérectomie. Acta endocr., Copenh. 52, 72.

Harris, G. W. \& Donovan, B. T. (1966) The pituitary gland. University of California Press.

RoBertson, H. A. \& RAKHA, A. M. (1965) The timing of the neural stimulus which leads to ovulation in the sheep. F. Endocr. 32, 383.

Rowlands, I. W. \& SHORT, R. V. (1959) The progesterone content of the guinea-pig corpus luteum during the reproductive cycle and after hysterectomy. F. Endocr. 19, 81 .

Schomberg, D. W., Coudert, S. P. \& Short, R. V. (1967) Effects of bovine luteinizing hormone and human chorionic gonadotrophin on the bovine corpus luteum in vivo. F. Reprod. Fert. 14, 277.

SHoRt, R. V. (1964) Ovarian steroid synthesis and secretion in vivo. Recent Prog. Horm. Res. 20, 303.

Short, R. V. \& Moore, N. W. (1959) Progesterone in blood. V. Progesterone and 20 $\alpha$-hydroxypregn4-en-3-one in the placenta and blood of ewes. F. Endocr. 19, 288. 